\title{
Long-term decomposition process of leaf litter from Quercus pyrenaica forests across a rainfall gradient (Spanish central system)
}

\author{
A Martín ${ }^{1}$, JF Gallardo ${ }^{2}$, I Santa Regina ${ }^{2}$ \\ 'Area de Edafologia, Facultad de Famacia, Universidad de Salamanca, 37080 Salamanca; \\ ${ }^{2}$ CSIC, Aptado 257, 3707I Salamanca, Spain
}

(Received 30 November 1995; accepted 1 April 1996)

\begin{abstract}
Summary - A long-term ( 3 years) study has been made of the leaf-litter decomposition process in four forest ecosystems across a rainfall gradient. The soil organic contents comply with the factor of rainfall, but this does not appear to affect the complete decomposition process decisively, since the limiting factor is soil humidity. The rainfall distribution is similar for all the plots studied and the main differences are seen essentially in the amount of water received during the wet season (in each case with sufficient humidity for leaf decomposition to progress). Thus, leaf-litter decay is linked to the maintenance of soil humidity, mineralization slowing down when the soil dries out, and the effects of climate therefore predominating over the chemical characteristics of the material in the regulation of the decomposition process (at least at short term). In this sense, the summer drought is the most unfavourable environmental factor in this type of climate. In advanced stages of decay the rate of weight loss becomes relatively independent of climate. The decomposition rates obtained by the litterbag procedure are lower than those calculated by litter production and permanent litter; the reason for these differences is probably the limitation of the mesofaune activity in the litterbags. Leaf decomposition constants ranged from 0.33 on the plot with the highest rainfall to 0.47 (on the driest plot), corresponding to mean residence times of 2.0 to 1.1 years, respectively. However, each bioelement has a different residence time.
\end{abstract}

leaf-litter decomposition / forest ecosystems / Quercus pyrenaica forests / Mediterranean climate / litter quality / litterbag methods

Résumé - Processus de décomposition à long terme des litières de chênaies à Quercus pyrenaica suivant un transect pluviométrique. On a étudié le processus de décomposition à longue terme ( 3 années) des feuilles de quatre chênaies à Quercus pyrenaica qui suivent un transect pluviométrique. Les contenus de matière organique des sols forestiers sont liés au facteur pluviométrique, mais la pluviométrie n'affecte pas de manière significative le processus de décomposition des feuilles

\footnotetext{
* Correspondence and reprints
} 
du chêne, car ce processus est plutôt affecté par l'humidité du sol. Cette distribution des pluies est similaire dans tous les sols forestiers, mais la différence de la quantité de pluie se manifeste en hiver, c'està-dire quand les sols sont humides. La décomposition est liée à l'humidité du sol, et elle est arrêtée quand le sol est sec. Ainsi l'effet du climat est plus important que la composition chimique à court terme; à long terme, l'importance du climat diminue. La constante de décomposition des feuilles obtenue par la méthode de « litter-bag » est plus basse que celle calculée à partir des donnés de production des litières et de la teneur en litière permanente, ce qui est dû à la limitation de l'activité de la mésofaune dans les «litter-hags ». Les constantes de décomposition varient de 0,33, dans la station la plus pluvieuse, à 0,47 , dans la station la plus sèche. Les temps de résidence varient de 2,0 à 1,1 années, respectivement. Il faut tenir compte du fait que chaque bioélément a son propre temps de résidence.

décomposition des litières / écosystèmes forestiers / Quercus pyrenaica / climat méditerranéen / qualité de la litière / méthode « litter-bag »

\section{INTRODUCTION}

In any forest ecosystem, both deciduous and evergreen, the litter fall is reflected each year in the massive appearance of dead organic matter that accumulates on the ground (Mangenot and Toutain, 1980). Together with the contribution from the decay of roots (McClaugherty et al, 1982), the litter on the surface of the soil represents the main source of energy, carbon, nitrogen and phosphorus for the soil microflora and mesofauna (Ranger et al, 1995) and also provides an amount of nutrients that can become readily available and be reused by the plant covering (Rapp and Leonardi, 1988).

It is customary to define two or three phases in the transfer of nutrients to the soil: in the first, soluble compounds are released by leaching; this is a rapid phase that depends on the initial nutrient content (Berg and Staaf, 1977). In the second phase, energetic compounds like cellulose and hemicellulose are decomposed immediately after that phase, thus making evident the degradation of the biological material. The third phase, which is much slower, affects molecules with bonds more resistant to degradation; this phase is carried out by soil organisms, essentially saprophytes (bacteria and fungi), and depends on the lignin content (Berg and Staaf, 1987).
The release of bioelements depends on the decomposition of organic matter and is generally proportional to weight loss. Many factors are involved in the release of bioelements. It should be stressed that apart from the intrinsic factors of the litter, such as the base content (Eijsackers and Zehnder, 1990), nitrogen (Berg and Staaf, 1980), polyphenols (Domínguez et al, 1988), lignin (Melillo et al, 1989), or tannins (Davies et al, 1960), there are external factors that also affect the decomposition rate; among these, of note are climate (temperature, humidity, aeration, actual evapotranspiration (AET); Berg et al, 1990; Dyer et al, 1990), soil characteristics ( $\mathrm{pH}$, base content; Kononova, 1966; Toutain, 1981) and soil organisms (Aranda et al, 1990; Kögel-Knabner et al, 1990; Joergensen, 1991).

In an ecosystem in equilibrium, the total mass of the contributions is compensated by the loss of an equal mass of litter; if this were not so, elements would be accumulated and retained by the litter, giving rise to a progressive decrease in productivity (Jenny et al, 1949; Mangenot and Toutain, 1980). Accordingly, an essential problem in forest ecology is to gain information about the laws governing the transformation of organic matter so that an excessive slowing down of biogeochemical cycles can be avoided.

Losses of organic matter due to the loss of carbon dioxide and leachates derived 
from decomposition are also important to consider, especially in managed woodlands (Howard and Howard. 1974).

The aim of the present work was thus to determine, in a long-term ( 3 years) study, the factors governing the decay of leaf litter in the different phases of the process and to compare different methods and calculations to estimate decomposition rates.

\section{DESCRIPTION OF STUDY AREA}

Four experimental plots in Quercus pyrenaica forests across a rainfall gradient were chosen. The plots are situated in the municipalities of Navasfrías, El Payo, Villasrubias and Fuenteguinaldo in the region known as El Rebollar on the northern face of the Sierra de Gata Mountains (southwest of the province of Salamanca).

The climate of the zone features rainy winters and warm summers and may be classified as temperate Mediterranean (Elías and Ruíz, 1977). The summer deficit in rainfall (189 $\left.\mathrm{mm} \mathrm{yr}^{-1}\right)$ is lower at Navasfrías, due to higher rainfall ( $1580 \mathrm{~mm} \mathrm{yr}^{-1}$ ) and lower temperatures (annual mean, $10.4{ }^{\circ} \mathrm{C}$ ). At Fuenteguinaldo the summer rainfall deficit (259 $\mathrm{mm} \mathrm{yr}^{-1}$ ) is significantly more marked owing to higher temperatures $\left(12.9{ }^{\circ} \mathrm{C}\right)$ and lower rainfall $\left(720 \mathrm{~mm} \mathrm{yr}^{-1}\right)$. Thus, the potential evapotranspiration (PET) calculated is $670 \mathrm{~mm} \mathrm{yr}^{-1}$ at Navasfrías and $730 \mathrm{~mm} \mathrm{yr}^{-1}$ at Fuenteguinaldo (Elías and Ruíz, 1977).

The tree stratum comprises $Q$ pyrenaica (Martín, 1995), the density varying between 1040 trees $\mathrm{ha}^{-1}$ at Villasrubias and 406 trees $\mathrm{ha}^{-1}$ at El Payo. The least dense plot has the highest mean trunk diameter $(25.4 \mathrm{~cm})$ and the greatest height $(17 \mathrm{~m})$, the lowest values corresponding to the plot at Villasrubias $(11 \mathrm{~cm}$ and $8.5 \mathrm{~m}$, respectively). The shrub stratum is present at the Fuenteguinaldo plot, with spiny or aphyllous leguminosae (Cytisus multiflorus,
Genista falcata) and spiny rosaceae (Rubus ulmifolius, Crataegus monogyna). In the herbaceous stratum there is a predominance of gramineae (Festuca sp, Dactilys glomerata), leguminosae only appearing at Fuenteguinaldo (Trifolium sp, Ornithopus $\mathrm{sp})$. As rainfall increases, the presence of ferns (Pteridium aquilinum) and. in forest clearings, of heathers (Erica sp, Calluna $v$ vulgaris) increases.

In all cases, the soils are Cambisols (generally humic) developed over slates and greywackes at Navasfrías and Villasrubias and over Ca-alkaline granite at EI Payo and Fuenteguinaldo (Gallardo et al, 1980).

\section{METHODS}

To follow the dynamics of leaf-litter decomposition on the soil, 54 nylon litterbags with a surface area of $4 \mathrm{dm}^{2}$ were placed on each plot. The bags had a pore mesh of $1 \mathrm{~mm}$ and were distributed in three groups of 18 bags distributed according to the topography (Martín, 1992). Each litterbag contained $10 \mathrm{~g}$ of recently fallen leaves. previously dried at room temperature, from the same stand. The bags were placed on the soil surface so that the conditions would be as close as possible to natural ones (Bocock, 1964).

The experiment started in February 1990) (the leaves were taken on November 1989). One bag was withdrawn from each group at approximately two monthly intervals until a sampling period of 3 years had been completed. At the laboratory, the samples were cleaned, dried at $80^{\circ} \mathrm{C}$ and the variations in dry matter calculated. Following this, the contents were ground and homogenized for the corresponding analytic determinations. In all samples the following were determined: organic carbon by the dry method using a Carmhograph 12 Wösthoff; total nitrogen by a Heraeus Macro- $\mathrm{N}$ analyzer; calcium and magnesium by atomic absorption spectroscopy; potassium by flame photometry and phosphorus by spectrophotometry (Martín, 1992).

In order to compare the results obtained in the experimentation with the true decay of the organic matter, different decomposition indices were determined (Martín, 1995); to do so, all the material of the holoorganic horizon contained in a $0.5 \mathrm{~m} \times 0.5 \mathrm{~m}$ frame was collected. Fifteen 
samples per plot were taken. Likewise, to determine the indices it was necessary to know leaflitter production, which was achieved by placing three series of ten boxes of $0.24 \mathrm{~m}^{2}$ surface area on each plot. The amount of litter falling into each box was collected at time intervals depending on the amount fallen, November being the month of major litterfall (Martín, 1995). All the material was dried at $80^{\circ} \mathrm{C}$ for $24 \mathrm{~h}$ and separated into different fractions (leaves, twigs, etc).

In order to establish possible significant differences in mass loss for the different plots studied, a one-factor analysis of variance (ANOVA) was applied with repeated mesures for times; obviously, a Hartley's test had been previously made in order to verify the identity of the variances. When significant results were obtained with ANOVA, Tukey's multiple comparison method was applied to determine the reason for the significance found.

Some bags were lost because of various accidents; to avoid using a different number of samples, the lower number of bags taken from the plots was taken into account in the ANOVA test $(n=52)$.

\section{RESULTS AND DISCUSSION}

Previous work (Gallardo et al, 1980) has shown that there is a relationship between the mean content of organic carbon, total nitrogen and the $\mathrm{C} / \mathrm{N}$ ratio of the $\mathrm{A}_{h}$ surface horizons of soils and annual rainfall. Using only the data from these plots (table I), Martín et al (1993) observed that the sequence of soil contents followed the rainfall gradient since the rainfall values recorded are $1580,1245,872$ and $720 \mathrm{~mm}$ year $^{-1}$ for the plots according to the Navasfrías to Fuenteguinaldo transect. However, it is more advisable to use data relating to soil humidity instead of rainfall (Moreno, 1994) because the processes of leaf decomposition and soil humification are carried out more intensely when there is an appropriate degree of humidity in the soil, this being more related to rainfall distribution than to annual rainfall (Berg et al, 1990).

Figure 1B shows the data on soil humidity (between 0 and $15 \mathrm{~cm}$ ) determined in situ (Moreno, 1994). Very dry periods between July and September of 1990 and between July and October 1991 and 1992 can be noted. The mean temperatures follow a regular wave pattern, so that no further reference is made to them (minimum in January, maximum in July). Additionally, the lowest soil humidity is observed at Fuenteguinaldo owing to lower rainfall, coarser texture of the soil and higher prevailing temperatures.

Detailed scrutiny of the decay curves (fig 1A) during the same period reveals that there are periods of continuous mineralization together with others when decomposition ceases. On comparing figures $1 \mathrm{~A}$ and IB it may be deduced that the halt in decay occurs nearly during the dry summer periods (taking into account that the litter dries

Table I. Contents in organic carbon (C) and total nitrogen (N) of the permanent litter and soil epipedons of the plots (referred to $20 \mathrm{~cm}$ depth).

\begin{tabular}{|c|c|c|c|c|c|c|c|c|c|}
\hline \multirow[t]{2}{*}{ Plots } & \multirow{2}{*}{$\begin{array}{c}\text { Soil } \\
\text { horizon }\end{array}$} & \multicolumn{2}{|c|}{ Organic $C$} & \multicolumn{2}{|c|}{ Total N } & \multirow[t]{2}{*}{$C / N$} & \multirow{2}{*}{\multicolumn{3}{|c|}{$\begin{array}{l}\text { Litter mass Litter C Litter } N \\
\left(M g h a^{-1}\right)\left(k g h a^{-1}\right)\left(k g h a^{-1}\right)\end{array}$}} \\
\hline & & $\left.\overline{\left(g k g^{-1}\right.}\right)$ & $\left(M g h a^{-1}\right)$ & $\left(g \mathrm{~kg}^{-1}\right)$ & $\left(M g h a^{-l}\right)$ & & & & \\
\hline Navasfrías & $A_{b}$ & 105 & 103 & 4.98 & 4.9 & 21 & 5.25 & 2335 & 57 \\
\hline El Payo & $\mathrm{A}_{\mathrm{h}}$ & 77 & 98 & 4.69 & 6.0 & 16 & 4.34 & 2035 & 52 \\
\hline Villasrubias & $\mathrm{A}_{\mathrm{h}}$ & 67 & 66 & 3.99 & 3.9 & 17 & 5.66 & 2616 & 73 \\
\hline Fuenteguinaldo & $A_{h}$ & 42 & 47 & 3.22 & 3.6 & 13 & 4.61 & 2139 & 67 \\
\hline
\end{tabular}



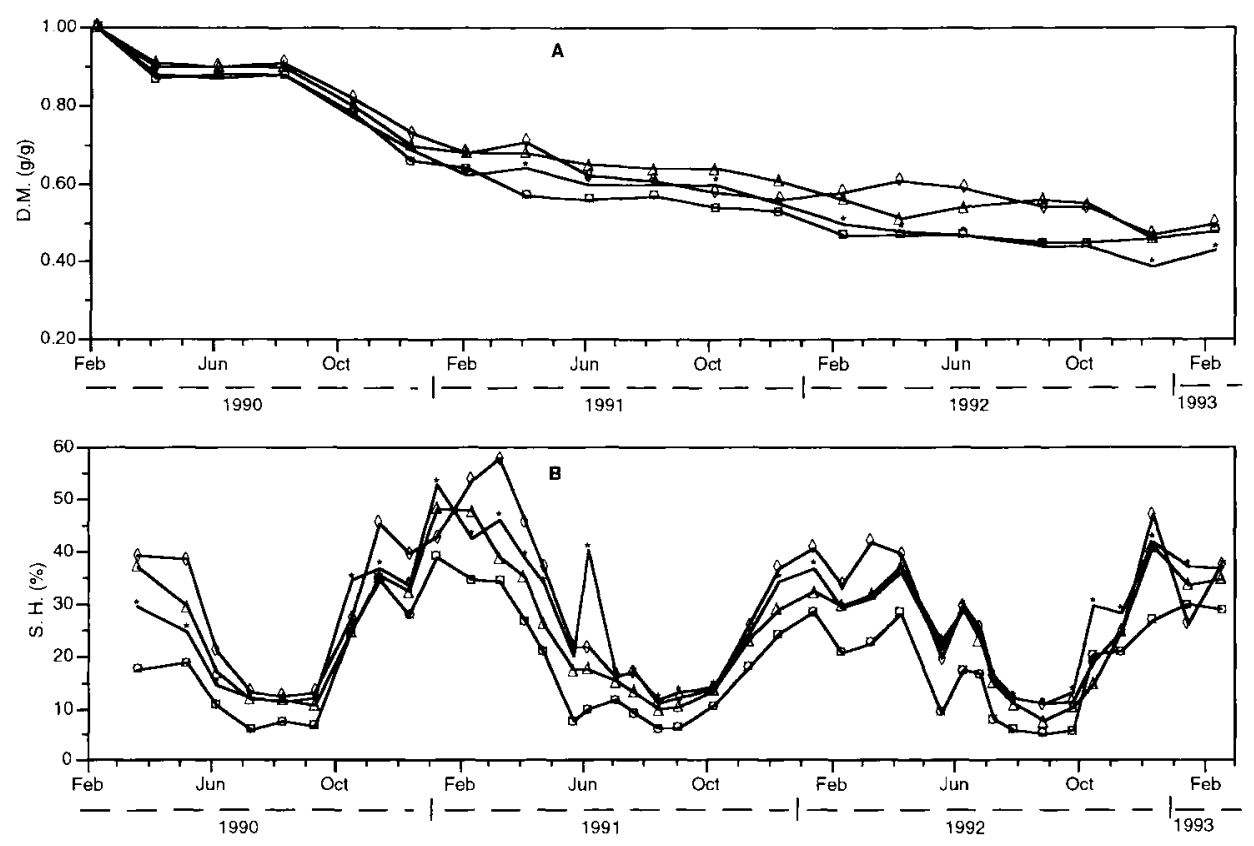

Fig 1. Evolution of the residual amount of dry matter (DM) in decaying leaves and of surface humidity $(\mathrm{SH})$ on the Quercus prenaica plots (*Navasfrías; $\wedge$ El Payo; $\diamond$ Villasrubias; $q$ Fuenteguinaldo).

before the soil, and wets also before the soil because of the dew effect), with mineralization continuing when humidity is high despite the lower temperatures; in this case, a temperature increase of a few degrees in the wet period has significant effects (Shanks and Olson, 1961). The effect of the dry period on leaf decay has been addressed in depth by Martín et al (1993). During the late decay phases the effect of dry periods is not detectable. As a result, in these forest ecosystems, leaf-litter decay is linked above all to humidity itself (Beyer and Irmler, 1991), with mineralization slowing down when the leaf litter is dry (the soil may continue to be moist to a depth of more than $40 \mathrm{~cm}$ ). Toutain (1981) stressed, however, that there are physical and physicochemical processes of decay in summer (losses of dry matter by animals, water or winds, could be limited).
Accordingly, the winter temperature does not appear to be a first-order limiting factor, as corresponds to a temperate climate subject to Mediterranean influence; rather, the seasonality of the humidity (necessary for biological activity) and of the rainfall (necessary for washing and the removal of solutes, micelles and microparticles towards the mineral horizons of the soil) would be responsible for this. Climate has a strong influence in the first phases of decay and, as mentioned earlier, an increase in temperature of just a few degrees during the wet period may have significant effects (Shanks and Olson, 1961). Thus, the higher decomposition constants observed in the first 2 years of the study are seen at Fuenteguinaldo (warmer) and at Navasfrías (rainier). Thereafter, decomposition decreases, influenced by molecules with more resistant bonds (Martín et al, 1993). 
Table II. Multiple comparisons of the means of residual dry matter (Tukey test) from an analysis of variance $(\mathrm{ANOVA} ; n=52 ; * * P<0.01$ and $\mathrm{ns}=$ not significant $)$.

\begin{tabular}{lcccc}
\hline Plots & Navesfrias & El Pavo & Villasrubias & Fuenteguinaldo \\
\hline Fuenteguinaldo & $\mathrm{ns}$ & $* *$ & $* *$ \\
Villasrubias & $* *$ & $\mathrm{~ns}$ & - \\
El Payo & $* *$ & - & \\
Navasfrías & - & &
\end{tabular}

On considering their decomposition rates, the four plots may be grouped by two's. On the one hand, there is Villasrubias-El Payo, with accumulated mass loss over 1,2 and 3 years of 32,43 and $53 \%$, respectively; on the other hand, there is NavasfríasFuenteguinaldo, with a higher decay rate $(37,52$ and $58 \%)$. The ANOVA results show that there are no significant differences for Villasrubias-El Payo and Navasfrías-Fuenteguinaldo, although there are important differences between both groups (table II).

Despite the seasonal fluctuations, the decay process can be represented by different types of regressions, with the best fits given by the following equations (significance $P<0.0001$ ):

\section{Navasfrías}

$$
\begin{aligned}
R=69.64 \mathrm{e}^{(-0.0005 t)}+ & 29.14 \mathrm{e}^{(-0.0027 n)} \\
R^{2} & =0.93 \quad n=54
\end{aligned}
$$

\section{El Payo}

$$
\begin{aligned}
R=67.90 \mathrm{e}^{(-0.0017 t)}+ & 32.29 \mathrm{e}^{(+0.0002 t)} \\
R^{2} & =0.94 \quad n=52
\end{aligned}
$$$$
\text { Villasrubias }
$$

$$
\begin{aligned}
& R=68.56 \mathrm{e}^{(-0.0017 t)}+ 31.93 \mathrm{e}^{(+0.0002 t)} \\
& R^{2}=0.93 \quad n=55
\end{aligned}
$$

\section{Fuenteguinaldo}

$$
\begin{aligned}
R=97.95 \mathrm{e}^{(-0.0013 t)}+1.42 \mathrm{e}^{(+0.0025 t)} & \\
R^{2} & =0.95 \quad n=55
\end{aligned}
$$

where $R$ is the residual dry matter expressed in percentage form and $t$ is the time in days elapsed since the start of the process.
In any case, the asymptotic fits show the same determination coefficients and almost the same residual squares as the double exponential equations. Accordingly, the following equations would be obtained (significant, $P<0.0001$ ):

\section{Navasfrías}

$R=26.6+71.74 \mathrm{e}^{(-0.0015 t)}$

$$
R^{2}=0.93 \quad n=54
$$

\section{El Payo}

$R=42.9+57.41 \mathrm{e}^{(-0.0019 t)}$

$$
R^{2}=0.94 \quad n=52
$$

\section{Villasrubias}

$R=44.1+56.54 \mathrm{e}^{(-0.0020 t)}$

$$
R^{2}=0.93 \quad n=55
$$

\section{Fuenteguinaldo}

$$
\begin{aligned}
& \left.R=39.2+61.59 \mathrm{e}^{(-0) .0024} \uparrow\right) \\
& \qquad R^{2}=0.94 \quad n=55
\end{aligned}
$$

where $R$ and $t$ are the same as in the previous case. In this case, the model points to the existence of one stable residue (more abundant at El Payo and Villasrubias) and one unstable one, which decomposes faster at Fuenteguinaldo (constant 0.0024 ).

In view of this, the above-mentioned double exponential and asymptotic equations applicable to the decomposition curves imply, in all cases and as has been mentioned, that the detritic material is composed of at least two fractions that decay at different rates. The asymptotic model shows that prolongation of the process elicits a decrease in the decaly rate per unit of time. 
The double exponential model confirms that there would only be one material formed of two components that decay at very different rates, although progressively over time (negative signs in the exponents) at the plot at Navasfrías. The fact that in the other three plots the double exponential equations are composed of the sum of one negative and another positive exponential points to the existence of two types of component: one that is released more or less rapidly and another that is accumulated progressively and that would therefore slow down the overall process. After a certain time (4.4, 4.1 and 2.6 years for El Payo, Villasrubias and Fuenteguinaldo, respectively), there would be no decay but rather an accumulation of decomposing material (the positive function would give higher values than the negative one and the double exponential function would pass through a minimum), which is difficult to understand in conceptual terms. This increase of dry matter could be explained by both a humification of the rapid decomposing fraction, and by an ingrowth of material coming from outside the bags (from the canopy or from the underlying layers by fungi). In this sense, Fuenteguinaldo would be the first plot to reach the point at which decay is arrested; that is, the point at which decay of the recalcitrant fraction should predominate because in this plot the initial rate is the most rapid. Likewise, it can be seen that this accumulation phenomenon is not seen at Navasfrías (the other plot with a high initial rate) because, according to the asymptotic equations, the resistant fraction would only represent $27 \%$ of the organic matter while at Fuenteguinaldo it would represent $39 \%$.

The effect cannot be attributed to the lithology in the sense that decaying leaves are hardly in contact with the soil and the differences in the chemical composition of the leaves (table III) are not determinant (Martin, 1995), with the exception of $\mathrm{N}$ and $\mathrm{P}$, which are slightly higher on the plots developed over granite. However, more importance could possibly be given to the content in bases of the surface horizon of the soil on which decay occurs since this parameter affects microbial activity (Dommergues and Mangenot, 1970); in this sense, it can be noted (table IV) that Fuenteguinaldo is the most favourable medium for decay (lower acidity, greater degree of saturation, high contents in assimilable Ca; table IV) while Villasrubias is the most unfavourable (higher acidity), although this could perhaps be accounted for, as already mentioned, in terms of leaf composition and could affect this more than the actual decay process. Indeed, the $\mathrm{C} / \mathrm{N}$ ratio of the leaves, sometimes used as an index of the facility of leaf decay (Duchaufour, 1984), is close to 35 in the plots on granite and to 44 in the plots on slates, in view of the more dystrophic nature of these soils

Table III. Initial chemical composition of decaying oak leaves on the different experimental forest plots (in $\mathrm{mg} \mathrm{g}^{-1}$ ). Mean of two replicates.

\begin{tabular}{lcccc}
\hline Plots & Navasfrias & El Payo & Villasrubias & Fuenteguinaldo \\
\hline $\mathrm{C}$ & & 483 & 490 & 478 \\
$\mathrm{~N}$ & 472 & 14.4 & 11.6 & 13.4 \\
$\mathrm{C} / \mathrm{N}$ & 10.6 & 34 & 42 & 36 \\
$\mathrm{P}$ & 45 & 1.1 & 0.8 & 1.1 \\
$\mathrm{Ca}$ & 0.7 & 9.4 & 7.9 & 10.5 \\
$\mathrm{Mg}$ & 10.3 & 1.3 & 1.8 & 1.3 \\
$\mathrm{~K}$ & 1.3 & 1.1 & 1.0 & 1.1 \\
\hline
\end{tabular}


Table IV. Bulk density (in $\left.\mathrm{g} \mathrm{cm}^{-3}\right), \mathrm{pH}$, base saturation percentage ( $\mathrm{V}$, in \%) and contents in assimilable Ca (in mg kg$~^{-1}$ and in $\mathrm{kg} \mathrm{ha}^{-1}$, referred to $20 \mathrm{~cm}$ soil depth) of the soil epipedons. Mean of two replicates.

\begin{tabular}{lcccccc}
\hline Plots & $\begin{array}{c}\text { Soil } \\
\text { horizon }\end{array}$ & $\begin{array}{c}\text { Bulk density } \\
g \mathrm{~cm}^{-3}\end{array}$ & $\mathrm{pH}$ & $\begin{array}{c}\mathrm{V} \\
\%\end{array}$ & $\begin{array}{c}\text { Assimilable Ca } \\
\mathrm{mg} \mathrm{kg}^{-I}\end{array}$ & $\mathrm{~kg} \mathrm{ha}^{-1}$ \\
\hline Navasfrías & $\mathrm{A}_{\mathrm{h}}$ & 0.59 & 4.9 & 7.5 & 300 & 294 \\
El Payo & $\mathrm{A}_{\mathrm{h}}$ & 0.95 & 4.7 & 5.2 & 800 & 1018 \\
Villasrubias & $\mathrm{A}_{\mathrm{h}}$ & 0.72 & 4.6 & 5.2 & 300 & 294 \\
Fuenteguinaldo & $\mathrm{A}_{\mathrm{h}}$ & 0.88 & 5.4 & 43 & 600 & 676 \\
\hline
\end{tabular}

(table III). However, in table II the differentiation according to the parent rock is not established.

If one wishes to compare the fit of decay using the litterbag technique with the real process, it is possible to compare the resulting decay indices with the previous technique $\left(k_{o}\right)$ and those calculated from the annual production of leaf litter and accumulated soil leaf litter, according to the formula:

$$
k^{\prime}=\mathrm{A} / \mathrm{A}+\mathrm{F}
$$

where $k^{\prime}$ is the decay index of Jenny (Jenny et al, 1949); $\mathrm{A}$ is the annual leaf litter production and $\mathrm{F}$ represents the leaves accumulated before the autumn fall. The results are shown in table $\mathrm{V}$. This table also shows the decay indices calculated from the in situ decay experiment (litterbags) both for the first year of decay and for the second and third years. In theory, in a natural untouched leaf litter, the first layer (L) of leaves would decay according to the first index, the second one $(\mathrm{F})$ according to the second index, and the third one $(\mathrm{H})$ according to the third index, the leaf litter here being almost humified according to the estimated mean residence time $(t r=\mathrm{F} / \mathrm{A}$; subhorizon $\mathrm{H})$ and becoming incorporated into the soil. In our forest plots, it is very difficult to distinguish the three organic subhorizons (which is very common in Mediterranean forest ecosystems).

Higher decay indices are seen on the granite plots than on those located on slates, both for leaf litter (table V) and for total litter (calculated in the same way; table VI). Additionally, the sequence of the indices does not evolve in a parallel fashion to the rainfall gradient, indicating that it is not the total amount of rain that governs the greater

Table V. Decomposition indices of leaves calculated using different techniques ( $k^{\prime}$ from the data on the mean leaf production of 3 years; $\mathrm{k}_{0}$, from the litterbags). $t r$ is the mean residence time (see text) in years. The data between parentheses are standard errors.

\begin{tabular}{|c|c|c|c|c|c|c|c|}
\hline \multirow[t]{2}{*}{ Plots } & \multicolumn{2}{|c|}{ Leaves $\left(k g h a^{-l}\right)$} & \multirow[t]{2}{*}{$\mathrm{k}^{\prime}$} & \multirow[t]{2}{*}{$k_{o / v e a r}$} & \multirow[t]{2}{*}{$k_{u 2 \text { yeur }}$} & \multirow[t]{2}{*}{$k_{r, 3 y e u r}$} & \multirow{2}{*}{$\begin{array}{c}\operatorname{tr} \\
\text { (year) }\end{array}$} \\
\hline & $\overline{\text { Production }}$ & Accumulation & & & & & \\
\hline Navasfrías & $2088(57)$ & $2808(276)$ & 0.43 & 0.38 & 0.12 & 0.11 & 1.3 \\
\hline El Payo & $2346(52)$ & $2224(80)$ & 0.51 & 0.32 & 0.12 & 0.10 & 0.9 \\
\hline Villasrubias & $2208(85)$ & $2621(163)$ & 0.46 & 0.32 & 0.10 & 0.11 & 1.2 \\
\hline Fuenteguinaldo & $2829(66)$ & $2602(117)$ & 0.52 & 0.36 & 0.17 & 0.01 & 0.9 \\
\hline
\end{tabular}


Table VI. Litter decay indices $(K)$ and mean residence times $(t r)$, calculated from the values of annual production $(A)$ and total accumulation $(F)$ of litter. The data between parentheses are standard errors.

\begin{tabular}{llcll}
\hline Plots & \multicolumn{2}{c}{ Litter $\left(\mathrm{kg} \mathrm{ha}^{-1}\right)$} & $\mathrm{K}$ & $\mathrm{tr}$ \\
\cline { 2 - 5 } & Production & Accumulation & & \\
\hline Navasfrías & $2601(82)$ & $5251(459)$ & 0.33 & 2.0 \\
El Payo & $3489(144)$ & $4344(249)$ & 0.45 & 1.2 \\
Villasrubias & $2831(116)$ & $5664(618)$ & 0.33 & 2.0 \\
Fuenteguinaldo & $4088(138)$ & $4611(281)$ & 0.47 & 1.1 \\
\hline
\end{tabular}

rate, and perhaps the greatest effect comes, at least in the first few stages of decay, as has been mentioned, from the distribution of the rainfall throughout the year together with air temperature, aeration and soil texture, humidity and the temperature of the surface horizon of the soil. Moreover, both the specific characteristics of the site and the chemical composition of the litter govern the nature of the heterotrophic community (Kögel-Knaber et al, 1990) and its presence and activity are linked to the physicochemical characteristics of the substrate (Toutain, 1981); that is, the coarser textures of the granite soils lead to lower water retention and a certain increase in soil temperature that will alter microbial activity.

From a comparison of the results (table $V$ ), it may be deduced that in their natural medium $\left(k^{\prime}\right)$ the leaves decay at a faster rate than in the nylon litterbags, which are inaccessible for the mesofauna (Bocock, 1964; Joergensen, 1991), which have a very important physical effect on the litter products. Martin (1995) reported that whereas at Navasfrías and Fuenteguinaldo the percentage of highly broken up leaves in the litter is greater than $90 \%$, with respect to the total of leaves, this percentage is only $74 \%$ at El Payo and $87 \%$ at Villasrubias. Thus, the initial rate of leaf breakage at those plots seems to be greater than at Villasrubias and El Payo, as happens in the litterbags. However, in more advanced stages of decay, the different rates undergo certain changes (the factors controlling the decay rate are different), making the residence times of the leaves in the soil ( $t r$ ) similar in the two plots located on granite, on the one hand, and in the two located on slates, on the other (table $V$ ), in an inverse ratio to the productions found.

What does seem clear is that on using the litterbag technique, one obtains decay indices $\left(\mathrm{k}_{\text {olyear }}\right)$ for the first year that are below the true values since the technique prevents the important role of breakage (Bocock, 1964) and that of microbiological insemination (Dommergues and Mangenot, 1970) by the mesofauna (that fact probably explains why, compared with other published data, the asymptotic values given here are relatively high. Accordingly, it would be more rigorous to consider the leaf decay constant $k^{\prime}$; or perhaps perform an integration of the different $k_{0}$ for the first 3 years (not the mean) since, as noted earlier, it is evident that layers of leaves of different ages in the leaf-litter decay at the same time which cannot be longer than 3 years because the mean residence time is not greater than 1.3 years; this value is lower than that found by Rapp and Leornadi (1988) in $Q$ ilex (5.3). With this theoretical approach, the values of the constants $k^{\prime}$ and $\mathrm{k}_{\mathrm{o}}$ would converge. Such a calculation of the true $k_{0}$ would be somewhat imprecise owing to the difficulty of separating the decaying leaves 
from the first, second and third years in the leaf litter. In any case, the true value of the constant would lie between $k^{\prime}$ and $k_{0}$.

It is also possible to set up indices that indicate the residence time for the litter on the basis of the expression (Richter, 1990):

$$
t r=F / A
$$

Thus, it can be seen (table VI) that the residence times for the litter are 2 years for the plots located on slates and about 1.2 years for those located on granite. This index could also be applied for the leaf fraction of the litter and for nutrients (table VII). In the case of the leaf fraction, the values of $t r$ are close to 1 year for the oak stands on granite and slightly more than 1 year for the other two. The highest values of $t r$ logically obtained for total litter can be explained in terms of the notion that it contains more lignous fragments, such as twigs and bark (Meentemeyer, 1978).

With respect to the $t r$ of nutrients, the lowest residence time corresponds to potassium (table VII). On comparing these residence times with those of the organic matter, it may be deduced that the residual leaf litter becomes impoverished in $\mathrm{K}$ and $\mathrm{Mg}$ since these bioelements are released faster than the loss of weight of organic matter; in contrast, the concentrations of $\mathrm{P}$. Ca and $\mathrm{C}$ remain almost constant. The behaviour of $\mathrm{N}$ depends on the type of plot considered; in the drier plots $\mathrm{N}$ is enriched whereas it is impoverished in the more humid ones.

\section{CONCLUSION}

The use of litterbags is a valid method for comparing the initial decomposition rates among ccosystems and for monitoring the evolution of the process although the method is not valid for estimating the true rate of the cycles since litterbags slow down the process. This slowing down occurs because the bags prevent access to part of the mesofauna and hence prevent its important role in breaking up the leaf litter. Thus, the decay achieved in the litterbags responds mainly to climatological factors, affording asymptotic or double exponential relationships that indicate the presence of components that do not decay readily.

The plots with the lowest fertility (those located on slates) have the lowest production of litter and the lowest decay rate. Their cycles are therefore slowed down with respect to those of plots located on granites (more fertile). However, the decay rate of the leaf fraction is initially seen to be altered by abiotic factors (temperature and the amount of rainfall). Additionally, the total amount of rainfall does not seem to decisively affect the complete decay process since this is influenced by soil humidity, and the annual excess of rainfall occurs

Table VII. Residence times (years) of leaves (DMl: dry matter leaves) and of different nutrients in the soil (accumulation/return due to litter fall).

\begin{tabular}{lcccc}
\hline Plots & Navasfrias & El Payo & Villasrubias & Fuenteguinaldo \\
\hline DMl & 1.3 & 0.9 & 1.2 & 0.9 \\
C & 1.9 & 1.2 & 1.9 & 1.1 \\
$\mathrm{~N}$ & 1.7 & 1.1 & 2.5 & 1.3 \\
$\mathrm{P}$ & 1.8 & 1.1 & 1.9 & 0.9 \\
$\mathrm{Ca}$ & 2.0 & 1.3 & 1.9 & 1.1 \\
$\mathrm{Mg}$ & 1.4 & 1.1 & 1.3 & 1.0 \\
$\mathrm{~K}$ & 0.8 & 0.7 & 0.8 & 0.7 \\
\hline
\end{tabular}


when the soil is humid, and hence this water only leads to an increase in soil acidity.

\section{ACKNOWLEDGMENTS}

The authors wish to thank the Junta de Castilla y León for allowing them to use the forest plots and the European Union (MEDCOP/AIR Program), I)GCYT/MEC and CICYT/INIA for financial support. The technical expertise of $\mathrm{D}^{\mathrm{a}} \mathrm{ML}$ Cosme, $\mathrm{D}^{\mathrm{a}} \mathrm{C}$ Pérez and DJ Hernánde\% is also acknowledged.

\section{REFERENCES}

Aranda Y, Serrano JM. Bermúdez F (1990) Degradación de la hojarasca de Popultes nigra L. Re' Ecol Biol Sol 27. 395-406

Berg B, Jansson PE, McClatugherty C (1990) Climate varriability and litter decomposition, results from a transect study. In: Landscape-Ecological Impact of Climatic Change (MM Borr. RS De Groot. eds). IOS Press, Amsterdam, the Netherlands. 250-273

Berg B, Staaf H (1977) Mobilization of plant nutrients in Scots pine forest moor in Central Sweden. Silia Fim 11,210-217

Bere B. Stat H (1980) Decomposition rates and chemical changes of Scots pine needle litter. II. Influence of chemical composition. In: Structure and Fuction of Northern Coniferous Forests $-A n$ Ecosyitem Study (T Persion, ed). Ecol Bull, Stockholin, Sweden, 32, 373-390)

Berg B. Staaf H (1987) Release of nutrients from decomposing white birch leaves and Scots pine needle litter. Pedobiol 30), 55-63

Beyer l., Irmler U (1991) The structure of humus and dynamic of litter decomposition on a Luvisol and a podzol under forests. Pealobiol 35, 368-380

Bocock KI (1964) Changes in the amounts of dry matter. nitrogen, carbon. and energy in decomposing woodland leal litter in relation to the activities of the soil lauma. J Ecol 52, 273-284

Davies RI, Coulson CB. Lewis DA (1960) Polyphenols in soil profile development. Sci Proc R Dublin Soc A-1. 183-189

Domínguez MT, González E, Penalva F (1988) Inlluencia de nutrientes y politenoles en la descomposición de la hojarasca de especies atutóctonas e introducidas en el Sureste español. An Edaf Agrobiol 47, 1429-1442

Dommergues Y, Mangenot Fi (1970) Ecologie microbieme du sol. Masison et Cic, Paris, France, 796p
Duchaufour Ph (1984) Edafología. I. Edafogénesis y clasificación. Masson, Barcelona, Spain, $493 \mathrm{p}$

Dyer ML. Mcentemeyer V. Berg B (1990) Apparent controls of mass-loss rate of leaf litter on a regional scale. Scand J For Res 5. 31$]-323$

Eijsackers H. Zehnder AJB (1900) Litter decomposition: a Russian matriochkil doll. Biogeochemistry 11. 15.3-174

Elías F. Ruíz L (1977) Agrod limalología de España. INIA. Madrid. Spain

Gallardo JF. Egido JA. Prat L ( 980 ) Suelos forestales de El Rebollar (Salamanca). I. Consideraciones generales. Amu Cent Edafol Biol Apl 6. 193-223

Howard PJA. Howard DM (1974) Microbial decomposition of tree and shrub litter. I. Weight losses and chemical composition ol decomposing litter. Oikos 25, 34\}-357

Jenny H. Gesiel SP, Bingham FT (1949) Comparative study of decomposition rates of organic matter in temperalc and tropical regions. Soil $S_{c} i$ 68. 419 4.32

Joergensen RG (1991) Organic matter and nutrient dynamics of the litter layer on a forest Rendzina under beech. Biol Feril Soils 11, 163-169

Kögel-Knabner I. Hatcher PG, Zech W (1990) Decomposition and humification processes in forest soils: implications from structural characterization of torest soil organic matter. In: Trans $14 t h \operatorname{lnt}$ Conge Sorl Sci ISSS. Kyoto, Japan, 5, 217-223

Kononova MM (1966) Soil Organic Matter, 2nd edn. Percamon Press. Oxford. UK. 544 p

Mangenot F. Toutain F (1980) I Les litières. In: Achlalités d'écologic forestiòre (P Pesson, ed), GauthierVillars. Paris. France, 3-69

Martín A (1992) Aportaciones al conocimiente del pocese de descomposición in situ de hojas de Quercus pyrenaica y Pinus pinaster. Trabajo de Licenciatura, Universidad de Salamanca, Spain, $145 \mathrm{p}$

Martín A (1995) Reciclado de biodementos a thates de la hojarasea en ecosistemas forestales de la Siema de Gana (Sistema Central español). Tesis Doctoral, Universidad de Salamanca, Spain, 356 p

Martín A, Ciallardo JF, Santa Regina I ( 1993) Dinámica de la descomposición de hojas de rebollo en cuatro ecosistemas forestales de la Sierra de Gata (provincia de Salamanca, España): índices de descomposición. Imest Agrar Sis Récur For 2. 5-17

MeClaugherty CA. Aber JD. Melillo JM (1982) The role ol tine roots in the organic matter and nitrogen budgets of two forested ecosystems. Ecology 63, $1481-1490$

Meentemeyer V (1978) Macroclimate and lignin control of litter decomposition rates. Ecology 59, 46.5472

Melillo JM. Aher JD. Linkins AE, Ricca A, Fry B. Nadelhoffer KL (1989) Carbon and nitrogen dynamics along the decaly continuum: plant litter to 
soil organic matter. In: Ecology of Arable Lands (M Clarholm, L Bergstrom, eds), Kluwer Academic Publ, Dordrecht, the Netherlands, 53-62

Moreno G (1994) Balances de agua y nutrientes en rebollares (Quercus pyrennaica Willd) de la vertiente salmantina de la Sierra de Gata. Tesis Doctoral, Universidad de Salamanca, Spain, $470 \mathrm{p}$

Ranger J, Colin-Belgrand M, Nys C (1995) Le cycle biogéochimique des éléments majeurs dans les écosistèmes forestiers. Étude Gestion Sols 2, 119-134
Rapp M, Leonardi S (1988) Évolution de la litière au sol au cours d'une année dans un taillis de chêne vert (Quercus ilex). Pedobiol 32, 177-185

Richter J (1987) The Soil as a Reactor. Catena-Verlag, Cremlingen

Shanks RE, Olson JS (1961) First-year breakdown of leaf litter in Southern Appalachian forests. Science 134, 194-195

Toutain F (1981) Les humus forestiers. Structure et modes de fonctionnement. Rev For Fr 33, 449-477 